\title{
EMPOWERMENT INEQUITY OF MICROFINANCE INTERVENTION: ROLE OF COMMUNICATION IN COMMUNITY PARTICIPATION
}

\author{
Shreya Patel \\ Research Scholar, Department of Management \\ Birla Institute of Technology, Lalpur \\ Ranchi, Jharkhand \\ Dr. Amar Nath Jha \\ Prof. \& Centre In-Charge, Department of Management \\ Birla Institute of Technology, Lalpur \\ Ranchi, Jharkhand
}

\begin{abstract}
It is assumed that microfinance through self-help groups is an accelerator of development and change. A self-help group is a voluntary association of 10 to 20 women from the disadvantaged section of the population who come together to save and avail credit from microfinance institutions and banks through a facilitating agency such as NGO. This paper reviews the scope and limitations of self-help groups in having an impact on the economic and social upliftment of its members by focussing on an empirical research conducted in the state of Jharkhand and review of existing literature. Majority of available literature focuses on the economic empowerment of women through microfinance intervention with miniscule focus on social empowerment through identified social empowerment variables. This study points out that economic empowerment has not translated into desired social empowerment for the beneficiaries of this program. The social empowerment of the marginalized is still a mirage. This paper investigates the reason for the same and the role of communication in gender sensitization and stakeholder participation as communication is a facilitator of social change. It aims towards understanding the linkage of community participation and communication for empowerment and propose suggestions for the same.
\end{abstract}

Keywords: Microfinance, Self-help Groups, Communication, Social Empowerment, Economic Empowerment, Community

\section{INTRODUCTION}

Initiated as a simple effort to keep Bangladeshi underprivileged women out of the clutches of moneylenders, microfinance has evolved as the twentieth century's one of the most radical development intervention. (Chowdhury, Mosley and Simanowitz 2004).

Microfinance is a non-conventional form of banking focusing on the marginalized category of the society. It is based on the concept that the poor are credit worthy and can pull themselves out of poverty if they have access to affordable loans. Access to credit facilities has gained attention in reference to the poverty alleviation and empowerment to women (Swain and Wallentin, 2009).

Over the past years many schemes have been introduced by the policy planners which aim at Financial Inclusion.Rural development has been a function of financial inclusion of the vulnerable resulting in self-dependence.
Microfinance has gained importance as a tool for economic development (Aruna and Jyothirmayi, 2011). Women are a significant proportion of beneficiaries.

Traditionally, women were not allowed to contribute to economic development. Women are more disadvantaged and have fewer entitlements. They are subjected to greater inequities in the access to food, education, healthcare as well as command over productive resources. They have less voice in decision making both in the house as well as the community. As pointed out by Patel and Jha, 2014 women are more likely to utilize their loans for productive purposes hence having a 'trickling down effect'. Poor men in rural areas tend to spend the money on alcohol and other non-necessities. However, the mother always puts her children and family before her and would strive to ensure better food, health, education and standard of 
living for her children. Hence the impact percolates to the household and community level. Microfinance opens opportunities for women to begin their new ventures (Sarumathi and Mohan, 2011). Additional income for the women is added by providing them training, the supply of raw material, marketing platforms, and investment or credits. There is a common perception among development planners and academia that economic empowerment automatically translates to social empowerment and increased status of women in the household, enhanced decision-making capability, improved access to health facilities, better education of children and so on. Many studies have shown that although women may be empowered in one sphere, it does not translate into empowerment into other areas. (Kishor, 2000; Kumar 2006) There are number of factors like structure inequalities, gender sensitization, patriarchy, communication loopholes to name a few.

From the existing literature it is observed that studies related to social impact of microfinance is skewed towards the southern and western states of India. Neither has the impact of communication on the SHG and the community been explored.

\section{Self Help Groups:}

A SelfHelp Group is a voluntary association of 10 to20 members (mostly women from similar background) who pool in their financial resources to avail credit from Microfinance Institutions, NGO's and Banks. The SHG promotes its members to regularly save small amount of money and then lends this money together with money availed from Bank to the needy members. Each week the members typically contribute around Rs 10 towards the group's collection box that represents the group's collective savings. These are known by different names in different regions like Mandal, Samiti, Samooh, Sangha and so on. In India SHG's are mostly concentrated on women and the focus is financial credit and savings. (Kumar, 2006)

\section{Concept of Empowerment}

Communities have started looking at the women's empowerment as a prerequisite of economic development. Female participation in the economy has become a primary concern all over the globe (Aruna and Jyothirmayi,
2011). SHG's have emerged as tool of women empowerment. The women who earlier were weak and single entity have gained confidence by being attached to a group. They have obtained relief from evil social customs, traditions, prejudices. It has been observed from various studies that empowerment cannot be enforced from the top; it is essentially a bottom-up approach. However, they have to be some handholding from the top.

Empowerment is a multi-dimensional process and has been defined in a variety of ways. The term may be interpreted situationally and contextually. According to Surekharao and Rajamanamma, 1999, empowerment of women helps them to realize their full identity, potential and power in all spheres of life. It consists of increased command over resources, greater access to information, autonomy in decision making, freedom from sudden financial crisis and ability to plan life in general. Empowerment of women is a process in which women can become organized to increase their reliance, rights to make decisions and controlling the resources in hand and eliminating their subordinates (Varghese, 2011). Kabeer (2005) explored and highlighted that although access to financial services does not make a vital contribution to economic productivity and social well-being, it does automatically empower women. As per the study conducted by Umashankar, 2006, it was asserted that access to credit resulted in women to become independent. The study further reiterated the fact that qualitative methods must be given due importance in understanding the role of SHG in women empowerment. Tripathi, 2015 in her study views empowerment as an approach to enhancing individual's capacity and skills which leads to greater participation, improved decision making and transformative action. She has identified four components of women empowerment, which are psychological, social, cultural and lastly economic and political empowerment.

\section{Communication Approaches by SHG's for Empowerment of Women}

Every community project or development program requires effective participation of all stakeholders involved in such project. The communication channels need to open among all participants to keep them abreast of the 
developments of the program. (Aruma, 2018). Communication is of paramount importance for exchange of ideas and information especially in community projects. Communication is a process whereby people exchange ideas, thoughts, feelings, views with other people individually or in groups using verbal and nonverbal signs and expression to convey their thought.

Communication is the livewire of our society as it connects individuals to one another, individuals to groups, social organizations, community, villages, towns, societies, government and non-government bodies, religious organizations etc. As pointed out by Obono,(2018) in a study in Nigeria that development communication needs to be dynamic and needs to integrate both traditional and modern channels of communication for effective delivery of message in the society. While selecting the approach to communication factors such as target group, participation, interactivity and accessibility needs to be considered. There is a coexistence of formal and informal modes of communication in rural areas. These channels are used to get various social, economic and health related information. A study done by Varma and Verma, (2017) in two rural villages in Rajasthan points out that rural people rely more on informal sources of communication like neighbors, elders, midwives, chaupal etc. as compared to formal modes of communication like radio, newspaper, dialogue with development officials and information by wall paintings related to health. These informal sources are disseminating a lot of information which the rural people believe and act upon.

There have been numerous programs for women empowerment and development by the governments. However, most of these projects have failed to deliver the expected outcome as both the parties involved in the process i.e. the program implementers and beneficiaries have not been prepared for the change. There are two types of approached needed to induce change. First is the externally induced change and the other is the change which is induced from within the individual. (Murthy et. all, 2010). While externally induced change does not yield long term benefits, the change which is from within and internally motivated brings about an overall change in the attitude and behavior of the individual.

John G and Etika D, (2019) have studied the effect and relevance of participatory communication in development projects in Nigeria. Participatory communication is a communication approach that brings all stakeholders together and engages them in discussion to address a common societal problem. It stresses that the people and communities should be agents of social change and not just passive beneficiaries of the development initiatives. This approach has been used to enlighten and sensitize beneficiaries and communities to the need of the program even before it has been initiated. Participatory communication firstly requires the change in the mindset of the communicators and stresses on the need to engage people in the planning, decision making and implementation phase of community projects like empowerment of marginalized through SHG's. This approach of communication leads to internally induced empowerment as all the stakeholders are involved in sharing of information, dialogue, discussion and opinions and can thereby take informed decisions.Unless people themselves are the drivers of social change, no amount of external aid, technology and interventions will bring a change in their standard of living.

Participatory communication has a direct relationship with the access to community media. Community media combines some of the major benefits and strategies of mass media and interpersonal communication. It involves the members from the local community. It is a part of social and behavior change communication (SBCC) approach which involves the art of storytelling with innovative technologies that can empower communities. (Granger et all, 2019). Sharing success stories of SHG members through this medium can yield positive results.

SHG's are of paramount importance in community development and women empowerment as they have been able to accomplish the task of coming together and taking collective action for change and empowerment. Community development takes place when a group of people in a community come together with an aim to bring a desirable and positive change in the 
lives of its members through the cooperative efforts of these people. The coming together of group members and working towards a common goal requires a precondition of effective communication among them. (Adedokum et all, 2010). When people connect with each other at the same level they develop mutual trust for collective action. As pointed out by Murthy et. all, (2010) there are essentially five approaches of communication in SHG's according to their stage of development. The first is Two-steps flow of communicationwhereby information first flows to the influencing individual or opinion leaders in a community. Next this information is transmitted by the opinion leaders to the individuals in the group in the local dialect. In context of SHG's the leader is extrovert literate member who usually receives the information from the government officials, bankers or department facilitators and disseminates this information to the other group members.

The next approach of communication is a Dialogue. A dialogue is an interpersonal communication process between two individuals like two members of a group narrating their personal experience about the membership of SHG in terms of changes in savings habit, credit provision, personal experiences within the family etc. Since it is an informal one to one communication, it carries a lot of important information. Since the SHG members are from similar neighbourhood and economic class there is a common base for dialogues. They most often discuss about loan repayment sources, prospects of their ventures, education of children, illness and the like. SHG Sammelan is the third form of communication. It is an annual gathering of all SHG members to discuss about the group's working, the problems encountered, interactions with outside parties like bankers, NGO facilitators, development officials etc. A sammelan is an important community initiative as it encourages the women to come out of their homes and freely interact with women of different neighborhood in that area. There is a feeling of oneness among members and free flow of ideas is facilitated.

An extension of a sammelan is a Community lunch which is the fourth approach of communication. Community lunches are arranged during sammelans, trainings for SHG's, orientation programs for new members. During community lunches the marginalized women form connections with each other and discuss common problems and solutions to the same. There is a feeling of oneness and community lunches facilities unity within the group. The members also share responsibilities during the arranging of such gatherings resulting in community participation and communication in informal settings. Rural India faces the structural barriers of caste and class. The caste system is the social stratification of people into different social classes and is defined hereditarily by birth. (Kumar A, 2007). Even among SHG member's caste hierarchy play a predominant role. Community lunches are an effort to break the formal hierarchy. Preparation of lunches, tea, clearing and cleaning the place fosters the feeling of group and not caste.

The last approach of communication is the Entertainment - Education Programs. These types of programs have been used by the government for inculcating awareness and educating the rural poor since a long time. The social issues dealt are mostly related to health such as educating about child and maternal health, HIV/ AIDS, small family norms and benefits etc. This approach of communication goes beyond the individual model and affects the community at large. Skits and street plays are organized where the outgoing and extrovert members mostly participate. Social evils such as dowry, alcoholism and domestic violence also form the theme of such plays. The theme of such skits is prepared by the SHG members during the Sammelans. Such programs can be a mobilizer of social change in communities.

These five approaches of communication within a SHG can be adopted simultaneously to strengthen the group, generate ideas and facilitate flow of information. Communication among the members within the SHG is a prerequisite of developing coordination among them. It enhances psychological empowerment within the group as they have a small group to fall back upon in event of crisis.

\section{RESEARCH METHODOLOGY}

\section{The Study - In context of state of Jharkhand}

Primary data has been collected through structured questionnaires, focussed group discussions and select case studies among 270 women respondents in the state of Jharkhand 
which happens to be one of the poorest states in the country. The finding of this study is based on both qualitative and quantitative data which tries to explore the linkages between economic empowerment and social empowerment of women SHG members and the role of communication and community participation in empowerment.

\section{Objective of the Study}

With the research background in mind, this study was undertaken to determine the functioning of self-help groups in Jharkhand, the channels of communication adopted to strengthen the relationship among members; to determine the economic impact of SHG's on its members and to evaluate the social impact of microfinance on its beneficiary clients in terms of decision making, health, empowerment, social networking and communication and crisis management.

\section{The Study Area, Sample and Methodology}

The state of Jharkhand has been selected for the study. Jharkhand state has been carved out of Bihar in the year 2000. The state is touted to be loaded with mineral resources but poor in agricultural production. Greater than as much as $75 \%$ of the total working people are engrossed in agriculture but generates only $20 \%$ of the total GDP of the state. It has a high percentage of tribal population and the region is characterized by extensive forests. The sex ratio is 948 females per 1000 males. The literacy rate is $66.41 \%$ with female literacy at $55.42 \%$. The pattern of society is principally patriarchal with a predominance of issues of class and caste. (Chakravarty et. all 2013, Kumar 2007). State wise Jharkhand ranks third with a whopping $36.96 \%$ of its population below poverty line, considering the bountiful natural resources available to the state this is a matter of concern for the government and other stakeholders.(www.rbi.org)

For including respondents from a vast geographically spread population, multistage judgemental sampling technique was used. The state of Jharkhand has five divisions. Two districts from each division have been chosen basis penetration of microfinance activities and network of well-established NGO's. Two blocks have been chosen from each district basis the large number of SHG's in these blocks. Three SHG's have been chosen from each block considering the age of SHG. Lastly five members have been selected from each SHG. These respondents were picked up on the basis of their position in the group, tenure of membership (minimum two years of SHG membership), willingness to discuss and disclose personal mattersand credit history. Hence 270 respondents formed the sample size for this study. Both quantitative and qualitative data has been used for the study. Qualitative data has been gathered by conducting case studies and focussed group discussions to gain an insight into the member's perception about their roles, status, expectations and achievements post SHG period. Interviews with field level officials, male family members, community members were also conducted to understand their viewpoint. This provided an opportunity to gain access and insight into the community's perception about the efficacy and working of SHG's.

\section{Economic and Social Impact Variables:}

Economic indicators are easier to study as these can be quantified and does not depend upon the individual judgement of the respondents. For this study four economic variables such as income, savings, assets and insurance has been considered.A major impact of the microfinance intervention depends on the social change in the lives of its beneficiaries. Social variables are difficult to measure as compared to its economic variables' counterpart. The responses are influenced by personal choices and memory recall method. More studies have focused on the economic empowerment aspect and the social aspect is often considered a spill over effect. Therefore, a study evaluating the social empowerment of women through microfinance intervention is considered imperative. This research tries to investigate the impact upon the five social variables namely decision making, health and immunization, empowerment, social networking and communication and crisis management.

\section{RESULTS AND FINDINGS}

\section{Socio Economic profile of Respondents}

Majority of the sample in the study belonged to the age group of $31-40$ years, and $86.3 \%$ were married women. $63 \%$ of the respondents were Hindus followed by $16 \%$ Christians. Most of the respondents had only a primary level of education, and three percent were 
illiterate. Agriculture is seen as a significant source of income among the respondents. Monthly household income was around Rs 4500 per month in most of the sample.

\section{Impact of SHG's on Economic Empowerment of Women}

The study has examined the assessment variables at the economic and social level. A pre SHG period and post SHG period data comparison has been done. Questionnaire has been distributed only once and pre SHG data has been gathered by memory recall method of respondents.

\section{Income}

Table 1- Annual Household Income - Comparison of Pre and Post SHG periods

\begin{tabular}{|c|c|c|c|c|}
\hline & \multicolumn{2}{|c|}{ Pre SHG-Period } & \multicolumn{2}{|c|}{ Post SHG Period } \\
\hline $\begin{array}{l}\text { Annual } \\
\text { Income }\end{array}$ & Frequency & Percent & Frequency & Percent \\
\hline$<=25000$ & 26 & 10 & 17 & 6 \\
\hline $\begin{array}{c}25001 \text { to } \\
50000\end{array}$ & 135 & 50 & 63 & 23 \\
\hline $\begin{array}{c}50001 \text { to } \\
75000\end{array}$ & 73 & 27 & 104 & 39 \\
\hline $\begin{array}{c}75001 \text { to } \\
100000\end{array}$ & 32 & 12 & 59 & 22 \\
\hline $\begin{array}{c}100001 \\
\text { and above }\end{array}$ & 4 & 1 & 27 & 10 \\
\hline Total & 270 & 100 & 270 & 100 \\
\hline
\end{tabular}

\section{Savings}

Table 2- Annual Household Savings - Comparison of Pre and Post SHG periods

\begin{tabular}{|c|c|c|c|c|}
\cline { 2 - 5 } \multicolumn{1}{c|}{} & \multicolumn{2}{c}{ Pre SHG-Period } & \multicolumn{2}{c|}{ Post SHG Period } \\
\hline $\begin{array}{c}\text { Annual } \\
\text { Income }\end{array}$ & Frequency & Percent & Frequency & Percent \\
\hline $\begin{array}{c}\text { No } \\
\text { Saving } \\
<=5000\end{array}$ & 68 & 25 & 0 & 0 \\
5001 to \\
10000 \\
10001 to \\
15000 \\
$\begin{array}{c}15001 \text { to } \\
20000\end{array}$ & 127 & 47 & 80 & 29 \\
$\begin{array}{c}20001 \& \\
\text { above }\end{array}$ & 7 & 18 & 90 & 33 \\
Total & 270 & 100 & 21 & 8 \\
\hline
\end{tabular}

\section{Assets}

Table 3 Assets (post joining SHG)

\begin{tabular}{|c|c|c|}
\cline { 2 - 3 } \multicolumn{1}{c|}{} & Frequency & Percent \\
\hline Increased & 151 & 56 \\
Decreased & 17 & 6 \\
No Change & 102 & 38 \\
Total & 270 & 100 \\
\hline
\end{tabular}

Insurance

Table 4- Insurance- Comparison of Pre and Post SHG periods

\begin{tabular}{|c|c|c|c|c|}
\cline { 2 - 5 } \multicolumn{1}{c|}{} & \multicolumn{2}{c|}{ Pre SHG Period } & \multicolumn{2}{c|}{ Post SHG Period } \\
\hline $\begin{array}{c}\text { Type of } \\
\text { Insurance }\end{array}$ & Frequency & Percent & Frequency & Percent \\
\hline No insurance & 188 & 69 & 126 & 47 \\
Life Insurance & 18 & 7 & 23 & 8 \\
$\begin{array}{c}\text { Health } \\
\text { insurance } \\
\text { Crop }\end{array}$ & 7 & 3 & 15 & 6 \\
$\begin{array}{c}\text { Insurance } \\
\text { Livestock } \\
\text { Insurance } \\
\text { Asset }\end{array}$ & 22 & 13 & 60 & 22 \\
Insurance \\
Total
\end{tabular}

A rise in annual household income is noted for the respondents across all income categories in the post SHG period. (Table 1) As evident from Table 2, 25\% of the respondents had no savings prior to joining SHG membership followed by $47 \%$ respondents having an annual savings of less than Rs 5000. It was observed that savings increased post SHG membership. All respondents developed the habit of savings, as it was mandatory to contribute small amount to the SHG savings fund per month.

$33 \%$ stated savings more than Rs 5001 and upto Rs 10000 and 30\% stated increase in savings to Rs 15,001 and above. $55 \%$ of the respondents reported anincrease in their assets and $37 \%$ said that there was no change in the assetownership post joining SHG. Majority of the sample stated that they had no insurance before being a member but growth in the crop and livestock insurance is observed post SHG membership.Overall, there has been betterment in the economic status of the members of the SHG. However, it is to be noted that this advancement is for the entire household and not only for the member as many a times the credit is taken for the husband's entrepreneurial venture, for children's education or to meet a family requirement.

\section{Impact of SHG's on Social Empowerment of Women}

It is evident from the table 5 that the membership of SHG has not led to the desired level of social empowerment. 
Table 5 - Impact of SHG's on Social Empowerment of Women

\begin{tabular}{|c|c|c|c|c|}
\hline \multirow{2}{*}{\multicolumn{2}{|c|}{ Social Variables }} & & \multicolumn{2}{|c|}{ Total } \\
\hline & & & Count & Col \% \\
\hline \multirow{9}{*}{$\begin{array}{l}\text { Decision } \\
\text { Making }\end{array}$} & \multirow{3}{*}{ Use of borrowed money } & Improved & 61 & 23 \\
\hline & & Decreased & 121 & 45 \\
\hline & & No change & 88 & 33 \\
\hline & \multirow{3}{*}{ Education of children } & Improved & 83 & 31 \\
\hline & & Decreased & 13 & 5 \\
\hline & & No change & 174 & 64 \\
\hline & \multirow{3}{*}{ Strength to protest against social evil } & Improved & 97 & 36 \\
\hline & & Decreased & 31 & 11 \\
\hline & & No change & 142 & 53 \\
\hline \multirow{9}{*}{$\begin{array}{l}\text { Healthcare and } \\
\text { Immunization }\end{array}$} & \multirow{3}{*}{ Immunization to children below the age of 10} & Improved & 161 & 60 \\
\hline & & Deteriorated & 4 & 1 \\
\hline & & No Change & 105 & 39 \\
\hline & \multirow{3}{*}{ Improved sanitation } & Improved & 173 & 64 \\
\hline & & Deteriorated & 12 & 4 \\
\hline & & No Change & 85 & 31 \\
\hline & \multirow{3}{*}{ Safe Drinking Water } & Improved & 55 & 20 \\
\hline & & Decreased & 14 & 5 \\
\hline & & No change & 201 & 74 \\
\hline \multirow{9}{*}{ Empowerment } & \multirow{3}{*}{ Domestic Violence } & Increased & 131 & 49 \\
\hline & & Decreased & 70 & 26 \\
\hline & & No change & 69 & 26 \\
\hline & \multirow{3}{*}{$\begin{array}{l}\text { Purchase of assets/ household items } \\
\text { independently }\end{array}$} & Improved & 79 & 29 \\
\hline & & Decreased & 43 & 16 \\
\hline & & No change & 148 & 55 \\
\hline & \multirow{3}{*}{$\begin{array}{l}\text { Respect in society has changed after } \\
\text { being part of the group }\end{array}$} & Improved & 139 & 51 \\
\hline & & Decreased & 30 & 11 \\
\hline & & No change & 101 & 37 \\
\hline \multirow{9}{*}{$\begin{array}{l}\text { Social } \\
\text { Networking } \\
\text { and } \\
\text { Communication }\end{array}$} & \multirow{3}{*}{ Interaction with outsiders } & Improved & 172 & 64 \\
\hline & & Deteriorated & 9 & 3 \\
\hline & & No Change & 89 & 33 \\
\hline & \multirow{3}{*}{ Role in community decisions } & Improved & 81 & 30 \\
\hline & & Deteriorated & 2 & 1 \\
\hline & & No Change & 187 & 69 \\
\hline & \multirow{3}{*}{ Use of mobile phones } & Improved & 183 & 68 \\
\hline & & Deteriorated & 23 & 9 \\
\hline & & No Change & 64 & 24 \\
\hline \multirow{6}{*}{$\begin{array}{l}\text { Crisis } \\
\text { Management }\end{array}$} & \multirow{3}{*}{ Confidence to face crisis } & Improved & 124 & 46 \\
\hline & & Deteriorated & 35 & 13 \\
\hline & & No Change & 111 & 41 \\
\hline & \multirow{3}{*}{ In a position to help others during a crisis } & Improved & 76 & 28 \\
\hline & & Deteriorated & 36 & 13 \\
\hline & & No Change & 158 & 59 \\
\hline
\end{tabular}


The extremely important observation is that economicempowerment has not directly translated tosocial empowerment. This contrasts with thestudy by Kumar et all, 2019 which wasconducted across eight districts of five states of central and eastern India. The study states that membership of SHG has a positive outcome on the social variables such as health and nutrition, collective action regarding public entitlements, improved decision-makingsability etc. The present study on Jharkhand states that the decision regarding use of borrowed money still rests with the male member of the family. The poor women do not enjoy the spending rights over their own income too. $64 \%$ respondents reported no change in decision making ability with regards to education of children and same was the case with regards to strength to protest social evils (53\%). The state of healthcare especially in rural India is still a cause of concern. The awareness related to health and medical facilities remain dismal. There has not been much improvement in terms of improved sanitation, immunization to children below the age of 10 and safe drinking water. The need of privacy and defecation is greater for girls' women than the male family members. The unavailability of proper sanitation facilities for women is the reason for chronic constipation, urinary infections, improper menstrual hygiene and many other health related issues (Pandya and Shukla,2018). Many cases of improved sanitation were an outcome of government's Swaach Bharat Mission and not necessarily as a direct outcome of membership of SHG.However, women do not have much say in installation of sanitation facilities due to power hierarchies existing in the household, socio-cultural constraints and hesitation in communicating personal matters.

Empowerment has been measured by three variables - reduction in domestic violence, purchase of major household items independently, respect in society after being a part of the group. Surprisingly $49 \%$ respondents reported a rise in cases of domestic violence by husband/ in-laws post joining SHG. Although gender equality is a basic development goal across countries, however incidences of violence against women is a pandemic affecting nations worldwide. Women are treated as second class citizens and such discrimination can translate into obvious societal and structural norms (Pandya and Shukla, 2018). Similarly, the decision regarding purchase of assets/ household items still vests with the head of the family or the male members of the family. After being a part of the group the interaction of the poor women with outsiders (people other than family members) has improved (64\%) They have started interacting with women from the distant neighbourhood, bank officials, facilitators, etc. However, the improvement is noticed in women who are more mostly leaders/ secretary of the group and are more outgoing. It is based on the positive deviance (PD) approach which suggests that in every group or community there are individuals whose strategies and uncommon behaviour help them to find innovative solutions to their problems and stand out among the group/ community while facing the same economic and social conditions (Khalid et all, 2019). The women still do not play an important role in community decision making. $69 \%$ of the respondents have mentioned that they still do not play any significant role in community decisions. Contrary to this there is a marked improvement in use of mobile phones post joining the SHG (68\%) The members get information regarding the meeting, savings and credit of the SHG on mobile phones. Despite being a member of the SHG for more than two years the members still do not have enough confidence to face personal crisis neither do they have the requisite corpus to help group members in time of emergencies. From these findings it is evident that membership of SHG has resulted in provision of credit and income generating activities but how much this contributed to social wellbeing and empowerment of women is still a matter of debate and discussion.

\section{Findings from Case Studies and Focussed Group Discussions}

Case Studies and Focussed Group Discussions were conducted to get a qualitative view into the lives of the SHG members. As Einstein had rightly remarked "Not everything that can be counted counts, and not everything that counts can be counted". Ten women respondents were selected to study their case history. These respondents were picked up on the basis of ease of contact, tenure of membership (minimum three years of SHG membership), willingness to discuss and 
disclose personal matters, position in the group and credit history. These methods gave the authors an in-depthinsight into the women's views, perspectives, experiences, family relations etc who otherwise remain silent and docile. Silence is a protective tool enforced by our patriarchal society that hides so many stories of these women. (Umashankar, 2006). Such personal narratives highlight the difference in expression and experiences of women living in the same structural context at the same time. The factors that affect such narratives are literacy levels, interpersonal relationships, power structure within the household, socialisation histories, cultural beliefs and relationships with neighbours and extended families. (Singh $S$, 2005).Findings from Case Studies and Focussed Group Discussions suggest that SHG membership has benefitted the underprivileged in many ways. A change of attitude and behaviour is apparent among the members. Participation in income generating activities has improved the confidence of the respondents.

There is a remarkable transformation of a local village woman from what she was 10 years back. (Kumar, 2007). There is a desire to excel, to do the best for her family especially children. Although she has a desire to contribute to community development, the existing patriarchy doesn't allow her to contribute significantly. The results from the discussions and case studies make us question the gender power relations within the household and within the community. Western feminism is based on the premise of equality between men and women. The same does not hold true in case of developing countries where women survive in a society and culture which is built on the principle of inequality between men and women. The husband and family continue to be the most reliable source of economic, social and cultural support. (Singh S, 2005).There is clear lack of participatory communication which could have led to a social and behavioural change. Although women are participating in community affairs, the percentage is very small.There is a hesitation to communicate with the opposite sex apart from her males of her own family. Poor level of infrastructure and services prevail in the villages and there is very less use of technology.
There is availability of credit for income generating activities. However, in cases of medical emergencies, social functions, death in the family and other crisis the women often resort to the local moneylender for immediate help. Many a times the credit availed for income generating activity is used for immediate consumption purpose and daily activities like expenses on food, school fees, health etc.

"Earlier when I needed money I had to beg in front of my husband. He works as a casual labour. Some days we didn't have the money to feed our children properly. I borrowed money from local moneylender to pay school fees. I wanted to send my children (2 daughters and 1 son) to school so that they could get midday meal at school. Post joining SHG I availed a loan of Rs 3000 and started selling pickles. Within 6 months I had my own steady source of income. Although it is not enough, now I don't have to ask anyone for money. I plan to join hands with two other members from my group and expand my business" (Respondent 64)

The women are burdened with both economic and non-economic activities. They are concurrently engaged in childbearing, childcare, looking after family, elders as well as participating in income generating activities thus exerting a greater strain on her own health and wellbeing. Non-economic household work is essentially done by the beti/ $b a h u$. These are unpaid, tiring and unending duties for which they hardly get any recognition and appreciation. Many of the farm activities which are physically challenging and tedious such as transplanting, weeding, harvesting and protection of crops is also done by the woman. They also need to take care of the cattle.

Clearly there is a disproportionate division of roles and responsibilities. A typical day in the lives of these marginalized women starts as early as $4 \mathrm{am} / 5 \mathrm{am}$ and ends only at $9 \mathrm{pm}$ with almost no rest in between. This type of physical labour takes a toll on the health of women and there is no relief even during sickness or pregnancy. Many a times the NGO facilitators/ government officials/ bankers do not relate to this type of physical and mental workload. They often categorize the members as non-motivated and indifferent to training programs. In most of the cases there is a clear lack of support from husband/ other family 
members on days when trainings and orientation programs are held. The selection of training is also influenced by the implementer's thought of what should be taught. There is a clear lack of sensitization of the stakeholders involved.

"These women are only interested in availing credit and not undergoing training. As soon as they get the money, they use it for consumption purposes. Although some of them are self-motivated and attend the training programs, most of them need to be forced to do so. They come late and give excuses. We try to explain to them that theses trainings are for their own benefit." (NGO facilitator)

The empirical data from this study points out that there has been a rise in cases of domestic violence post SHG membership. $49 \%$ of women reported an increase in domestic violence whereas $26 \%$ reported no change in the current situation. The women have been subjected to domestic violence since time immemorial which has been hidden within the four walls of the house. Mostly violence is accompanied by a threat of desertion due to which the victim feels more helpless and is not willing to share her story with others. The scope for bargaining over power is maximum at the household level and goes on diminishing at the institutional and community level. While the physically bruises and wounds slowly become fainter the emotional wounds destroy the very spirit (Umashankar, 2006). Although the woman is an earning member of the family still, she is quite powerless within her own household. Generally, the woman stays back due to family pressure and for sake of her children. Neither does she have the confidence nor the financial resources to manage on her own.

My husband did not approve of me joining any group. He accused me of shoving my household responsibilities and making merry in name of group meetings. He also questions my character. My mother in law instigates him. He beats me at night after drinking and takes away my day's earnings. I complained to my parents many a times, but they have said that it is the kismat of a woman. They fear that I would leave my husband and become a lifelong burden on them. I don't discuss about this with group members as my husband would lock me up and beat me to death if he comes to know. (Respondent 19)
Although women have collectively become powerful and have combated certain social issues such as alcoholism, lack of electricity, access to anganwari services yet many of them are still shy and unwilling to participate in community works. Mutual support among the women is a prerequisite for their empowerment. The effective communication and mentoring of new members by the leader/ veteran SHG member has been extremely helpful.

\section{CONCLUSION}

It has been argued by many researchers that women's participation in SHG's has resulted in poverty alleviation and socio-economic empowerment of women. Empowerment gains are not an automatic outcome of availability of credit services to the poor. (Kabeer and Noponen, 2005). Although gains in terms of income, savings, and financial literacy skills are evident, impact on decision making ability and involvement in community matters are far from modest. Microcredit has been regarded to fix social challenges and the results of this study reiterates the fact that SHG and microcredit has not empowered its members socially to the levels expected. The command over resources and decision making still rests with the male member of the family. Although availability of microfinance has reduced the dependence on informal modes of lending, there is slight improvement in social variables like healthcare. One generation of exposure to credit and income generating activities cannot diffuse the centuries old patriarchy, social and cultural conditioning. (Osmani, 1998)

The five approaches to communication mentioned above focuses on flow of information among the SHG members. It boosts the synergy and bonding between the group members and encourages potential members to join the group. However, it failed to look at the broader picture. SHG operates in a community and the family members, community members, local leaders have not been adequately sensitized on the issue.Sustained improvement in gender relations can be achieved through repeated communication with regards to behaviour centred change communication. (Granger et all, 2019) 
Participatory communication is a salient aspect or approach of communication that fast-tracks development projects. To achieve success requires that priority should be given to the component of participatory communication when undertaking community projects. Development agencies and change agents should as a matter of fact allocate enormous attention to community involvement/ participation as this is key to the successful completion and realisation of set goals. Effective communication will help the marginalized to break out of the age-old culture of silence and discuss issues and challenges faced by them (Aruma, 2018). They need to be more assertive and vocal in a community forum. The important tool of communication should be explored adequately to reach the different sections of the community. A regular and direct communication with the community leadership is necessary.

The social impact of microfinance goes beyond the individual beneficiary of the program and percolates to the household and then the society. Hence the development planners and stakeholders can focus on strengthening the social aspect of the program. It depends upon the societal structure, existing gender relations and flow of communication to the indirect beneficiaries of the program. The community at large needs to be sensitized towards the poor women. The women have been burdened with the dual responsibility of income generation, childcare and household responsibilities. The men especially need to be sensitised on gender equality issues. Here community participation is extremely important for real advancement and empowerment. Development communication needs to address the social and cultural complexities and include all groups within the community to address the problem at the grass root level (Obono, 2018)

The microfinance intervention rarely addresses the gender specific issues and lack of mentoring and communication on the same. There are major inequalities and power imbalances between both the genders in society. By advocating a top down approach, the program implementers miss out on the actuality of women's lives and the existing power roles in the society. Improper communication leads to absence of participatory planning and total information regarding the program benefits does not percolate to each member of the group. An examination of the existing gender roles, command over resources, free flow of communication, gender-based division of labour is of paramount importance prior to the implementation of such interventions. The need of the hour is a gender transformative policy and sensitisation and counselling of all family members and community involved.

The communication approaches of SHG's such as two flow communication, dialogue, sammelan many a times lack community participation. Trainings are imparted to SHG members for skill development, financial literacy, accounting etc. However, it can also be the male trainer who firstly needs to be mentored to change his preconceived notions regarding the poor women. There is also a need to sensitize the facilitators, policy implementers, local leaders and male family member on gender specific issues. This can be a highly sensitive task and can hurt the ego of the male stakeholders involved. Hence the communication needs to flow in the appropriate manner and from a person who is looked upon by others. There needs to be a change in behaviour of not only the male member but also other elderly women in society who support such patriarchal structure in society. Public perceptions and awareness need to be altered to provide a supportive environment at the community level.

This study concludes that solutions such as microfinance and SHG's which emerge from international policy circles need to consider the local structural issues to maximise their results. This study has focused on certain specific social impact variables of microfinance; future work can be conducted on a set of comprehensive variables. Also, it is suggested to conduct a similar study on the other tribal areas of India and compare its impact.

\section{REFERENCES}

Adedokun M.O., Adeyomo C.W., Olorunsal E.O. (2010) The Impact of Communication on Community Development, Journal of Communication, 1(2), pp. 101-105.

Aruna, M. and Jyothirmayi, M. R. (2011). The role of microfinance in women empowerment: 
A study on the SHG bank linkage program in Hyderabad (Andhra Pradesh). Indian Journal of Commerce \& Management Studies 2(4), pp.77-95

Aruma E.O. (2018) Roles of Communication in Community Development, International Journal of Network and Communication Research, 5(1), pp. 1-10

Chakravarty S, Kumar A, Jha A N (2013) Women's Empowerment in India: Issues, Challenges and Future Directions, International Review of Social Sciences and Humanities, 5(1), pp.154-163

Chowdhury M, Mosley P, Simanowitz A (2004) The Social Impact of Microfinance Journal of International Development, 16, 291300

Granger K, Booher P, Cunningham S, Cotes G, Nicholson J (2019) Community Media for Social amd Behaviour Change: The Pwer and Principles of participatory Storytelling, Journal of Development Communication, 30(2), pp. 3651

John G and Etika D N (2019) Sustainable Development through Participatory Communication: An assessment of selected community projects in Cross River State, Nigeria, Journal of Development Communication, 30(2), pp. 60-71

Kabeer N (2005) Gender Equality and Women's Empowerment: A critical analysis of the third millenium development goals, Gender and Development, 13(1), pp.13-24

Kabeer N, Noponen H (2005) Socioeconomic Impact of PRADAN's Self Help Group Microfinance and Livelihoods Promotion Program, The Institute of Development Studies, Working paper No. 11

Khalid M Z, Ahmed A, Shayiq A B (2019) Changing Technology, Emerging Development: Sustainable Development in Rural India through mobile telephony, Journal of Content, Community and Communication, 10(5), pp. 39-49

K Surekharao, J Rajamanamma (1999) Empowerment of rural women through DWCRA programme, National Conference on Empowerment of Women

Kishor S (2000) 'Women's contraceptive use in Egypt: What do direct measures of empowerment tell us?' Paper prepared for presentation at the annual meeting of the Population Association of America, March 2325, Los Angeles, California

Kumar A (2006) Self Help Groups, Women's Health and Empowerment: Global thinking and contextual issues, Jharkhand Journal of Development and Management Studies, 4(3), pp. 2061-2079

Kumar A (2007) Health inequity and women's self-help groups in India: The role of Caste and Class, Health Sociology Review, 16(2), 160-168, DOI: 10.5172/hesr.2007.16.2.160

Kumar N, Raghunathan K, Arrieta A, Jilani A, Chakrabari S, Menon P, Quisumbing A (2019) Social networks, mobility and political participation: The potential for women's selfhelp groups, to improve access and use of public entitlement schemes in India, World Development 114, pp. 28-41

Murthy D.V.R., Haranath S and Arjun P (2010) Use of Communication by SHG's for Empowerment of Women, The Journal of Social Work, 71(4), pp. 613-621

Pandya M.N. and Shukla P.S. (2018) Role of Women Led Sanitation in Community Development, Journal of Content, Community and Communication, 7(4), pp. 71-77

Patel S and Jha A.N. (2014) Scope Enlargement of Microfinance Through Optimum Use of Existing Infrastructure and Manpower Jharkhand Journal of Social Development,7(1), pp. 1-7

Obono K (2018) Non-Modern and Modern Systems of Communication the Nigerian Publics: Integrating Non-Modern and Modern Systems of Communication for Community Development, International Journal of Communication: An Interdisciplinary Journal of Communication studies, 23,pp. 37-54

Osmani L (1998) Impact of Credit on the Relative Well-Being of Women: Evidence from the Grameen Bank, IDS Bulletin, 29(4)pp. 31-38

Sarumathi S \& K Mohan (2011) Role of Microfinance in Women's Empowerment-An Empirical study in Pondicherry region rural SHG's - Journal of Management and Sciences, 1(1), pp. 1-8

Singh S (2005) Deconstructing 'gender and development'for 'identities of women', International Journal of Social Welfare, 16, pp. 100-109 
Swain, R. B., \& Wallentin, F. Y. (2009). Does microfinance empower women? Evidence from self-help groups in India. International Review of Applied Economics, 23(5), pp. 541556.

Tripathi S (2015) Need of Psychological Empowerment of Women in India, Journal of Content, Community and Communication, 1(1), pp. 35-40.

Umashankar D (2006) Women's Empowerment: Effect of Participation in Self Help Groups, Indian Institute of Management, Bangalore -560076
Varma M and Verma A (2017) Rural Development and Channels of Grassroot Communication- With Reference to Health Information, Journal of Content, Community and Communication, 6(3), pp. 101-110

Varghese, T (2011). Women empowerment in Oman: A study based on Women Empowerment Index. Far East Journal of Psychology and Business, 2(2), pp. 37-53.

Table 154 - Below Poverty Line, rbi.org.in updated on 15th September 2019 